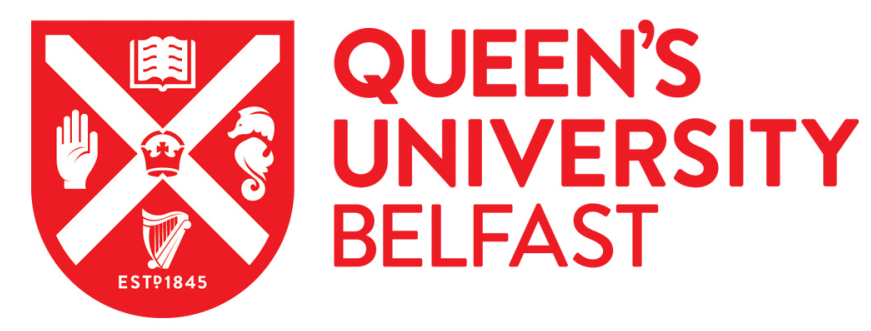

\title{
Labour Provisions in EU and US Mega-regional Trade Agreements: Rhetoric and Reality
}

Melo Araujo, B. (2018). Labour Provisions in EU and US Mega-regional Trade Agreements: Rhetoric and Reality. International and Comparative Law Quarterly, 67(1), 233-253.

https://doi.org/10.1017/S0020589317000422

\section{Published in:}

International and Comparative Law Quarterly

\section{Document Version:}

Peer reviewed version

\section{Queen's University Belfast - Research Portal:}

Link to publication record in Queen's University Belfast Research Portal

\section{Publisher rights}

(C) 2017 Cambridge University Press.

This work is made available online in accordance with the publisher's policies. Please refer to any applicable terms of use of the publisher.

\section{General rights}

Copyright for the publications made accessible via the Queen's University Belfast Research Portal is retained by the author(s) and / or other copyright owners and it is a condition of accessing these publications that users recognise and abide by the legal requirements associated with these rights.

Take down policy

The Research Portal is Queen's institutional repository that provides access to Queen's research output. Every effort has been made to ensure that content in the Research Portal does not infringe any person's rights, or applicable UK laws. If you discover content in the Research Portal that you believe breaches copyright or violates any law, please contact openaccess@qub.ac.uk. 


\title{
LABOUR PROVISIONS IN EU AND US MEGA-REGIONAL TRADE AGREEMENTS: RHETORIC AND REALITY
}

\author{
Dr. Billy Melo Araujo* \\ To be published in the International Comparative Law Quarterly - January 2018
}

\begin{abstract}
The EU and the US have long called for the linking of trade and labour standards in trade agreements at both the multilateral and bilateral level. This article examines their practice of including labour provisions in trade agreements, with a particular focus on recent attempts to include such provisions on so-called "mega-regionals", which were presented by their proponents as providing the benchmark for labour protection in future trade agreements. It discusses the rationale behind the inclusion of such provisions and their practical limitations, and examines the extent to which mega-regionals address these limitations. It is argued that whilst the EU and the US have been keen advocates for trade-labour linkages, there has also been an unwillingness to convert this rhetoric into practice, raising questions about the extent of their commitment to these values.
\end{abstract}

\section{Keywords:}

International Economic Law, WTO Law, Labour, TPP, TTI

\section{INTRODUCTION}

The requirement to adopt minimum labour standards is now standard practice in free trade agreements (FTAs) negotiated by major trading powers such as the EU and US. However, such practice has historically been contested by developing countries, who contend that the requirement to increase labour and social protection standards is designed to remove one of the few competitive advantages that developing countries have over developed countries in attracting foreign investment. More recently, the EU and the US have also sought to use so-called 'mega-regionals' such as the US-backed Trans-Pacific Partnership (TPP) and the EU-US Transatlantic Trade and Investment Partnership (TTIP) to promote labour standards. This was a significant development in that their proponents were keen to stress that these agreements would set the template for labour protection provisions in FTAs. On the US

* Lecturer, School of Law, Queen's University Belfast, B.Melo-Araujo@qub.ac.uk. This article was produced in the framework of a research project entitled "Sustainable Development in EU FTAs: A tool for the promotion of development goals or disguised protectionism?" funded by British Academy/Leverhulme Small Research Grants (SRG 2014-15). The article is a revised draft of a paper presented in the "Post-Brexit Britain in A World of Preferential Trade Agreements (PTAs)" conference held at the University of Birmingham on 24 February 2017. I am grateful to Sara Breen and the anonymous reviewers for their insightful comments on the earlier draft. 
side, it was claimed that the TPP would contain the "strongest labour provisions of any trade agreement in history" and would provide "a benchmark for future agreements". ${ }^{2}$ The EU claimed that the TTIP would provide an opportunity to negotiate "the most comprehensive set of fundamental international standards of labour rights [...] ever contained in a trade agreement". ${ }^{3}$ At the time of writing, the US has abandoned the TPP and TTIP negotiations have stalled to a halt. Nevertheless, the final text of the TTP and the negotiating drafts of the TTIP released by the EU can give us an indication of the grand visions espoused by these two trade powers for the future of labour provisions in trade agreements. This paper aims to assess the labour provisions included in these mega-regionals to determine the extent to which these agreements mark a significant departure from past FTA practice. The paper posits that not only do both agreements not veer too far from established EU and US FTA templates, but also that they serve to illustrate that, as far as labour protection standards in EU and US FTAs are concerned, there is a significant disconnect between the rhetoric and practice. Whilst both players have been keen advocates of trade-labour linkages, and have included substantive labour-related obligations in their FTAs, they have also failed or proved themselves reluctant to implement and enforce such provisions in practice, raising the question of whether these provisions amount to little more than a veneer. Section 2 of the paper examines the rationale behind the push for the inclusion of labour protection standards in trade agreements as well as the ultimate rejection of such proposals at the multilateral level. Section 3 discusses the manner in which the EU and the US have sought to disseminate minimum labour protection standards through FTAs and examines the limits of this practice. Section 4 discusses how mega-regional FTAs, in particular the TTIP and the TPP, were packaged by their proponents as the most ambitious FTA provisions on labour issues to date, and analyses the extent to which this claim is justified in the text or proposed text of these agreements. This section will also discuss how the recent collapse of these agreements may affect the trade-labour linkage issues in future EU and US FTAs.

\section{RATIONALE FOR TRADE LABOUR LINKAGE}

The linking of trade and labour protection standards is typically based on economic and values-based arguments. From an economic perspective, there is the notion that divergences in labour standards between different countries lead to unfair competitive advantages in global trade. The 'competitive advantage' argument is that lower cost of labour allows exporters to sell goods and services at cheaper prices and allows these countries to attract foreign investment. The lowering of standards can also be used for protectionist purposes, insofar as a country may opt to reduce labour costs domestically in import competing sectors. ${ }^{4}$ There is also a related concern that, as the global economy becomes more integrated, firms may be tempted to move their production and processing facilities to where labour costs are lower. This may then lead to a race to the bottom, as the adoption of lower standards in some countries would cause other countries to lower their own standards in order to counteract the supposed unfair competitive advantage gained by the former. ${ }^{5}$ Historically, the solution proposed to this perceived problem has been to use trade agreements to impose minimum standards of labour protection and enable trading partners to impose trade sanctions

\footnotetext{
1 USTR, "The Trans-Pacific Partnership: protecting Workers" December 2013. Available at: https://ustr.gov/sites/default/files/TPP-Protecting-Workers-Fact-Sheet.pdf

${ }^{2}$ Ibid.

3 Cecilia Malmstrom, "TTIP: What consumers have to gain" 26 January 2016. Available at: http://trade.ec.europa.eu/doclib/docs/2016/january/tradoc_154173.pdf
} 
against trading partners that fail to comply with or enforce such standards for protectionist purposes (so-called social clause ${ }^{6}$ ). The objective thus pursued is to iron out, or at least minimise, divergences in labour standards between countries.

The 'competitive advantage' argument has been widely and heavily disputed for a number of reasons. Firstly, there is little empirical evidence to suggest that lower labour standards significantly affect trade flows or foreign investment. ${ }^{7}$ In this respect, studies have shown that, in developing countries, non-export industries tend to apply lower labour standards compared to export-oriented industries. ${ }^{8}$ In addition, the political economy literature is divided on the idea that low labour standards in some countries will lead to a race-to-thebottom. ${ }^{9}$ Whilst there is some evidence that investors in some sectors may be attracted to countries that maintain low labour rights, there is also evidence that low labour standards can constitute a deterrent to foreign investment. ${ }^{10}$ The race to the bottom contention is also problematic because it ignores the fact that domestic labour standards typically reflect differences in productivity as well as societal choices which depend on the level of economic development of a given country. ${ }^{11}$ Developed countries tend to adopt high standards of labour protection not only because there is there a political demand from their constituents to do so, but also because they are able to absorb the resulting costs. By contrast, many developing countries are simply not in a position to achieve "a trade-off between monetary and nonmonetary wealth". ${ }^{12}$ Finally, the use of trade sanctions as a tool to coerce third countries to maintain minimum standards of labour protection has also been criticised, not least because such sanctions tend to produce adverse consequences for all parties involved: a trade sanction will invariably lead to price increases, which will simultaneously cause welfare costs for the

${ }^{4}$ Kyle Bagwell and Robert W. Staiger "Domestic Policies, National Sovereignty and International Economic Institutions” 16(2) (2001) Quarterly Journal of Economics 535.

${ }^{5}$ Maria Artuso and Carolan McLarney, "A Race to the Top: Should Labour Standards be included in Trade Agreements?” (40(1) 2015 Perspectives, 5

${ }^{6}$ Virginia A. Leary, "Workers' Rights and International Trade: The Social Clause (GATT, ILO, NAFTA, US Laws)" in Robert Hudec and Jagdish Bhagwati (eds.), Fair Trade and Harmonization: Prerequisites for Free Trade?, (Cambridge MIT Press, 1996) 177-231.

${ }^{7}$ See Dany Rodrik, "Labour Standards in International Trade: Do they matter and what do we do about them?", in Robert Lawrence, Dany Rodrik and John Whalley (eds.) Emerging Agendas for Global Trade: High Statkes for Developing countries, Policy Essay no.20 Overseas Development Councik, Washington D.C.; Remy Bazillier, "Trade, environment and labour,", Institut du Development duravle et des relations Internationales, No.08/2005, p.11-13.

${ }^{8}$ Robert Stern and K Terrell, "Labor standards and the World Trade Organization", World Trade Organization, August 20003, . Available at http://fordschool.umich.edu/rsie/workingpapers/Papers476500/r499.pdf

${ }^{9}$ See Robert G. Blanton and Shannon L. Blanton, "Labor Rights and Foreign Direct Investment: Is There a Race to the Bottom?" (2012) 38(3) International Interactions 267-294; Vivek Dehejia and Yagadeesen Samy, "Trade and Labour Standards: A review of the theory and new empirical evidence" The Journal of International Trade \& Economic Development (2004) 13(2) 179-198

${ }^{10}$ Matthias Brusse and Sebastian Braun, "Trade and investment effects of forced labour: An empirical assessment" (142 (2003) International Labour Review 49-71; C., Granger and Jean-Mark Siroen, "Core Labour Standards in Trade agreements: From Multilateralism to Bilateralism", (2006) 40(5) Journal of World Trade 827; Mita Aggarwal, "International Trade, Labor Standards, and Labor Market Conditions: An Evaluation of the Linkages", June 1995 USITC, Office of Economics Working Paper No. 95-06-C.

${ }^{11}$ Bernard Hoekman and Martin Kostecki, "Towards Deeper Integration? The "Trade and' Agenda" in Bernard Hoekman and Martin Kostecki, (eds) The Political Economy of the World Trading System: WTO and Beyond, (Oxford University Press, 2001), 415. For a review of the empirical data on this issue see: Vivek Dehejia and Yagadeesen Samy, supra footnote 9, 197

12 Gary Burtless, Robert Lawrence, Robert Litan and Robert Shapiro, Globaphobia: Confronting Fears about Open Trade (The Brookings Institution, Washington D.C, 1998), $122 .$. 
country applying the sanction and economic deterioration in the country subject to the sanction. ${ }^{13}$

Given the conflicting evidence surrounding the economic arguments, some scholars have put forward value-related arguments to justify the trade-labour linkages. ${ }^{14}$ The argument here is that, to the extent that certain labour rights are also recognised as fundamental human rights, there is a moral imperative to withhold market access where countries fail to apply universally accepted human rights such as the prohibition of slavery or child labour. ${ }^{15}$ However, this argument is limited by the fact that the claim to universality of such rights can be disputed. As explained by Bhagwati, the importance attached to particular rights often varies significantly depending on the cultural preferences and economic conditions of each country. ${ }^{16}$ Some have pointed to the success of the International Labour Organisation in setting minimum labour standards - evidenced by the large number of countries that have signed on to ILO conventions - an indication of a multilateral consensus on the fundamental labour rights. ${ }^{17}$ But this claim is countered firstly by the fact that developing countries have regularly contested the universality of rights recognized under the $\mathrm{ILO}^{18}$ and, secondly, that the ILO's large membership is in part due to the fact that non-compliance with ILO standards does not lead to the imposition of any type of sanctions. ${ }^{19}$ This leads on to another problem with the values-based argument, which relates to the apparent double standards held by those countries promoting trade-labour linkages. Although many of the main proponents of the trade-labour linkages advocate the use of trade agreements to promote international labour protection standards, they themselves often fail to comply with international labour law obligations. The EU, Canada and the US, for example, have been shown to be in violation of a significant number of ILO standards". ${ }^{20}$ The perception that is thus created, for those that would oppose the inclusion of labour issues in trade agreements, is that values-based arguments are merely intended to mask primarily economic agendas and that trade-labour linkages are viewed by developed countries merely as a tool to export labour rights to developing countries.

${ }^{13}$ Martin Will and Keith E. Maskus, "Core labor standards and competitiveness: implications for global trade policy", Review of International Economics 9.2 (2001), 317-328; Bernard Hoekman and Martin Kostecki (2001), "Towards Deeper Integration? The 'Trade and' Agenda" in Bernard Hoekman and Martin Kostecki, (eds) The Political Economy of the World Trading System: WTO and Beyond, (Oxford University Press, 415.

${ }_{15}^{14}$ Andrew T. Guzman, “Trade, Labor, Legitimacy” (2003) 91 California Law Review 901

15 Eddy Lee, "Globalization and Labour Standards: A Review of the Issues" (1997) 136(2) International Labour Review, 173-89; George Tsogas, "Labour standards in international trade agreements: an assessment of the arguments" (1999) 10(2) The International Journal of Human Resource Management 363; Jagdish Bhagwati, "Trade Liberalisation and 'Fair Trade' Demands: Addressing the Environmental and Labour Standards Issues" The World Economy [2001] 18(6), 753-755.

${ }^{16}$ Ibid; Manfred Weiss, "International Labour Standards: A Complex Public-Private Policy Mix" (2013) 29(1) Journal of Comparative Labour Law and Industrial Relations 13.

${ }^{17} \mathrm{G}$. Tsogas, supra footnote 15,363

18 Daniel Maul, "Human Rights, Development and Decolonization: The International Labour Organization”, 1940- 70. (New York: Palgrave Macmillan. 2012), 277.

${ }^{19}$ G. Tsogas, supra footnote 15, 363. D. Peksen and R. G. Blanton, "The impact of ILO conventions on worker rights: Are empty promises worse than no promises?" (2017 12(1) The Review of International Organizations, 75-94.

${ }^{20}$ David Weissbrodt and Matthew Mason, "Compliance of the United States with International Labor Law", (2014) 98 Minn. L. Rev. 1878; Joo-Cheong Tham and Kenneth Ewing "Labour Clauses in the TPP and the TTIP: A Comparison Without a Difference?", Melbourne Journal of International Law [2016] 3-35. Available at: http://scholarship.law.umn.edu/faculty_articles/368. 1878. 
The above considerations show why the trade-labour linkage is by no means an uncontroversial issue. This is further demonstrated in the conflicting positions adopted by different WTO Members when discussing proposals for the incorporation of rules on labour within the remit of WTO law. ${ }^{21}$ These proposals were part of the wider efforts by developed countries in recent decades to go beyond the traditional focus in international trade law on tariffs and non-discrimination by addressing regulatory issues such as competition, procurement and investment, trade facilitation (so-called 'Singapore issues') ${ }^{22}$ as well as nontrade issues such as environmental protection ${ }^{23}$. The WTO membership has, however, consistently rejected most of these proposals, in large part because developing country members have sought to maintain the organisation's focus on traditional market access issues of importance to them and consistently opposed new regulatory issues which they see as attempts to erode regulatory autonomy. ${ }^{24}$ With respect to labour, the US has traditionally packaged their proposals in economic language based on 'race to the bottom' arguments. ${ }^{25}$ Conversely, the EU has tended to promote trade-labour linkages by focusing on the normative dimension of the proposals and in particular by emphasizing the "universal nature of labour standards". ${ }^{26}$ However, proposals for the negotiation of WTO rules on the relationship between trade and labour rights have long been rejected by developing country WTO Members because of the perception that the real objective pursued is to protect developed countries against the competitive advantage of the availability of low skilled labour in developing countries. ${ }^{27}$

\section{PAST FTA PRACTICE}

\section{Labour protection in EU and US FTAs}

Whilst the EU and the US failed in their attempts to introduce labour standards within the framework of WTO law, they have been able to pursue this agenda in the context of bilateral and regional trade agreements, where they can leverage their market size more potently to secure concessions. ${ }^{28}$ Both EU and US FTAs include dedicated chapters with respect to labour standards, which tend to follow a fairly similar approach as far as labour protection is concerned. ${ }^{29}$ The overall aim is to use FTAs to promote and disseminate internationally recognised labour standards and to ensure that trading partners do not

21 Gonzalez Montserrat Garibay, "Trade-Labour Linkage from the Eyes of the Developing Countries: A Euphemism for Protectionist Practices", The Eur. Foreign Aff. Rev, 14 [2009], 763.

22 WTO, The Singapore Ministerial Declaration, adopted on 13 December 1996, ${ }_{23}^{\text {WT/MIN(96)/DEC. Available at: http://www.wto.org/english/thewto_e/minist_e/min96_e/wtodec_e.htm }}$

${ }^{24} \mathrm{~S}$ Evennett, 'Five hypotheses concerning the fate of the Singapore issues in the Doha Round' (2007) 23 (3) Oxf Rev Econ Policy 392-414. See also K Gallagher, 'Understanding developing country resistance to the Doha round' (2007) 15(1) Review of international political economy 62-85.

25 Montserrat Gonzalez Garibay, "Trade-Labour Linkage from the Eyes of the Developing Countries: A Euphemism for Protectionist Practices" (2009) 14, Eur. Foreign Aff. Rev. 763.

${ }^{26}$ Ibid, 769.

${ }^{27}$ Larry DiMatteo, Kiren Dosanjh, Paul L. Frantz, and Peter Bowal, "The Doha Declaration and Beyond: Giving a Voice to Non-Trade Concerns Within the WTO Trade Regime” Vand. J. Transnat'l [2003] L. 36, 124.

28 David Kleimann, "Negotiating in the Shadow of TTIP and TPP: The EU-Japan Free Trade Agreement" (June 20, 2015). German Marshall Fund of the United States, Asia Program, Policy Brief, June 2015. Available at SSRN: https://ssrn.com/abstract=2633660.

29 The US typically includes a "Labour" chapter in its FTAs whilst the EU FTAs include "sustainable development" chapters which address both labour and environmental protection issues. 
deliberately weaken social protection in order to gain a competitive advantage in international trade.

Firstly, they generally require parties to implement minimum internationallyrecognised labour standards. Such standards cover both labour rights (e.g., freedom of association, collective bargaining and the prohibition against child labour) and rules on working conditions (e.g., minimum wage and social security rights) enshrined in treaties negotiated under the auspices of the International Labour Organisation (ILO) ${ }^{30}$

Secondly, the FTAs contain provisions requiring parties not to lower labour standards or refrain from enforcing such standards in order to attract foreign investment. ${ }^{31}$ Although the commitments to maintain and uphold levels of labour protection are phrased in strong terms, rather than as a best endeavour obligation, the normative implications of such provisions are not entirely clear. Firstly, broad references to 'domestic labour laws' indicate that these obligations go beyond the mere application and enforcement of minimum standards enshrined in the international instruments listed in the FTAs. The obligation is wide in scope in that it covers any form of domestic legislation relating to labour or environment protection issues. However, the agreements do not define more precisely what would constitute a labour law, nor do they list the laws of FTA parties that would be covered by such obligations.

Another practical difficulty presented by such clauses is that they would only be applicable if the lowering of standards is designed "to affect" trade between parties or promote foreign investment. There is no guidance provided in EU or US FTAs clarifying how to determine the trade effects of the failure to apply or enforce labour standards, although in a recent decision delivered by the arbitral panel established in the context of a dispute between the US and Guatemala concerning the alleged violation of labour provisions under the Dominican Republic-Central America-United States Free Trade Agreement (CAFTA-DR) ${ }^{32}$ the first arbitral ruling concerning labour provisions in a US FTA - it was ruled that "a failure to effectively enforce a party's labor laws through a sustained or recurring course of action or inaction is 'in a manner affecting trade between the Parties' if it confers some competitive advantage on an employer or employers engaged in trade". ${ }^{33}$ In doing so, the arbitral panel opted for a broad interpretation of the term "affecting trade" which rejects the notion that nonenforcement can only 'affect trade' if it causes a change in prices of or trade flows in particular goods or services. ${ }^{34}$ Instead, the panel accepted that non-enforcement of domestic

\footnotetext{
${ }^{30}$ For a review of ILO standards see: Philip Alston, “Core labour standards' and the transformation of the international labour rights regime", European Journal of International Law 15.3 (2004): 457-521; Jordi Agustí-Panareda, Franz Christian Ebert, and Desiree LeClercq. "ILO Labor Standards and Trade Agreements: A case for consistency" Comp. Lab. L. \& Pol'y J. [2014] 36347.

${ }^{31}$ See Samantha Velluti, "The EU's social dimension and its external trade relations" in Axel Marx (ed.) Global governance of labor rights - Assessing the effectiveness of transnational public and private policy initiatives (Edward Elgar, 2015): 42-62. Lorand Bartels, "Social issues: Labour, environment and human rights" in Simon Lester, Bryan Mercurio and Lorand Bartels (eds), Bilateral and regional trade agreements: case studies - Volume II (Cambridge University Press, 2016),364;

${ }^{32}$ Final Report of the Panel in the Matter of Guatemala - Issues Relating to the Obligations Under Article 16.2.1(a) of the CAFTA-DR, 14 June 2017. Available at: http://trade.gov/industry/tas/Guatemala\%20\%20\%E2\%80\%93\%20Obligations\%20Under\%20Article\%20162-1(a)\%20of\%20the\%20CAFTA-DR\%20\%20June\%2014\%202017.pdf.

${ }^{33}$ Ibid Paragraph 190

${ }^{34}$ Ibis Paragraph 165.
} 
labour laws affecting a substantial number of workers for a significant amount of time could, on its own, be deemed to confer a competitive advantage on employers engaged in trade. ${ }^{35}$

The substantive labour protection provisions of EU and US FTAs are complemented by procedural frameworks which are intended to ensure the implementation of these agreements and to promote future cooperation on labour matters that arise between the parties. The US FTAs establish Labour Affairs Councils composed of representatives of both parties who meet annually to discuss various issues pertaining to the implementation of a review of labour provisions. ${ }^{36}$ They also establish mechanisms for cooperative consultations that are intended to resolve labour related disputes amicably. ${ }^{37}$ The EU sustainable development chapters typically establish two separate cooperative frameworks. ${ }^{38}$ Such cooperative frameworks fit with the EU's historically "soft" approach towards trade-labour linkages - that is, one that is based on continued dialogue and cooperation, rather than "hard" prescriptive rules. Firstly, the agreements create institutional bodies where cooperation between the parties can occur. This includes the requirement for each party to establish a contact point within each party's administration which can be used by the other party in order to address queries regarding the implementation of the sustainable development chapter provisions. The agreements also create committees on trade and sustainable development composed of officials from each side. The task of these committees is to oversee the implementation of the agreement and discuss matters of common interest or any other matter within the scope of the chapters on a regular basis. ${ }^{39}$ The committees are then supplemented by advisory bodies which comprise independent representative organisations of civil society, representing labour groups, business organisations and other relevant stakeholders. ${ }^{40}$ These are consultative bodies which can be used by stakeholders to make recommendations on the implementation of sustainable development chapters.

There are, however, some notable differences between the EU and the US approaches. Firstly, although both the EU and the US FTAs refer to ILO standards, the scope of standards covered by US FTAs is narrower than that of EU FTAs. US FTAs typically require parties to maintain laws, regulations and practices in accordance with the core labour standards established by the ILO Declaration on Fundamental Principles and Rights at Work. ${ }^{41}$ These core standards represent minimum labour protection standards, which are also recognised as fundamental human rights and include the freedom of association, the elimination of all forms of forced labour, abolition of child labour and the requirement of non-discrimination with respect to employment and occupation. ${ }^{42}$ By contrast, the scope of EU FTAs often extends

${ }^{35}$ Ibid Paragraph 193.

${ }^{36}$ Article 18(5) US-Australia FTA; Article Article 17(5 US-Colombia FTA; Article 16(4) CAFTADR FTA; Article 19(5) KORUS.

${ }^{37}$ Article 18(6) US-Australia FTA; Article 17(1) US-Colombia FTA; Article 15(6) US-Bahrain FTA; Article 16(6) CAFTA-DR FTA; Article 19(7) KORUS.

${ }^{38}$ See, for example, Articles 189 and 195 CEPA; Articles 13.12 - 13.15; Article 283-285 ColombiaPeru FTA, Articles 294-297 EU-CA FTA; Article 13.15 EU-Singapore FTA.

${ }^{39} \mathrm{Se}$, for example, Article 195 EU-CARIFORUM FTA; Article 13(3) EU-Korea FTA; Article 280 EU-EU Colombia/Peru FTA.

${ }^{40}$ See, for example, Article 13-13 EU-Korea FTA; Article 282 U-Colombia/Peru FTA; Article 238 CETA.

${ }^{41}$ Ferdi De Ville, Jan Orbie, and Lore Van den Putte, "Sustainable development in TTIP: a highest common denominator compromise?" European Journal of Risk Regulation 2 (2016), 291.

${ }^{42}$ Robert Kissack, "Labour Standards. An Historical Account of the EU Involvement with (in) the ILO" in Amandaine Orsini (ed.) The European Union With (in) International Organisations: Commitment, Consistency and Effects Across Time (Ashgate, 2016): 76-77. 
beyond core labour standards by also requiring parties to maintain laws in accordance with the ILO Decent Work Agenda ${ }^{43}$ and, in the case of the EU-Central America FTA, by requiring compliance with ILO conventions which regulate the core ILO standards, such as ILO Convention 87 concerning Freedom of Association and Protection of the Right to Organise and ILO Convention 98 concerning the Application of the Principles of the Right to Organise and to Bargain Collectively ${ }^{44}$. Such difference in scope between the EU and the US FTAs is explained to a large extent by the fact that that the US, unlike EU Member States, is not a signatory to most ILO Conventions. ${ }^{45}$ With respect to the requirements to not derogate, waive or fail to enforce labour protection standards, there is one EU FTA that adds to this practice by providing that parties must not lower "the level of protection provided by domestic social and labour legislation". ${ }^{46}$ This 'non-lowering' clause effectively requires parties to lock in existing levels of labour protection". ${ }^{47}$

However, the main difference between the EU and the US approach lies in the enforceability - or lack thereof - of such obligations. US FTAs adopt a "conditional approach"48, as they typically subject labour provisions to a dispute settlement mechanism and allow the suspension of benefits against a FTA party if it is shown that non-enforcement resulted from a sustained or recurring course of action or inaction and has occurred in a manner affecting trade or investment between the parties. ${ }^{49}$ By contrast, the EU adopts a "promotional" approach ${ }^{50}$, which places an emphasis on dialogue to promote labour standards and does not subject its sustainable development chapters to the FTA dispute settlement mechanisms. ${ }^{51}$ The upshot is that whilst the obligations included in these chapters are legally

${ }^{43}$ See Article 13(1) Free Trade Agreement between the European Union and its Member States, of the one part, and the Republic of Korea OJ L 127; Article 191(2) Economic Partnership between the CARIFORUM States, of the one part, and the European Community and its Member States, of the other part OJ L289/I/3. Article 23(3) Comprehensive Economic and Trade Agreement between Canada on the one part and the European Union and its Member States (CETA). The CETA was signed on 30 October 2016 and is currently awaiting approval from the European parliament. The parts of the agreement that fall under the EU's exclusive competence will be provisionally applied once the European Parliament's approval is secured. Those parts that fall within the EU's shared competence will only enter into effect following ratification by each EU Member State. Text available at: http://trade.ec.europa.eu/doclib/docs/2014/september/tradoc_152806.pdf.

44 Article 286(2) Council Decision of 25 June 2012 on the signing, on behalf of the European Union, of the Agreement establishing an Association between the European Union and its Member States, on the one hand, and Central America on the other, OJ L 346.

${ }^{45}$ Ferdi De Ville, Jan Orbie, Lorre Van de Putte, "TTIP And Labour Standards", Directorate general for Internal Policies Department: Economic and Scientific Policy, IP/A/EMPL/2015-07, p.33. Available at: http://www.europarl.europa.eu/RegData/etudes/STUD/2016/578992/IPOL_STU(2016)578992_EN.pdf.

${ }^{46}$ Article 193 EU-CARIFORUM EPA.

${ }^{47}$ Lorand Bartels, "Social issues: Labour, environment and human rights" in Simon Lester, Bryan Mercurio and Lorand Bartels (eds), Bilateral and regional trade agreements: case studies - Volume II (Cambridge University Press, 2016), 381.

${ }^{48}$ Franz Ebert and Anne Posthuma, "Labour Provisions in Trade Arrangements: Current Trends and Perspectives", ILO International Institute for Labour Studies Working Paper (2011), Geneva.

${ }^{49}$ See for example Articles 174)(5) and Annex 20A US-Singapore FTA; Roman Grynberg, "Labour Standards in US and EU Preferential Trading Arrangements" 40(4), 632-633; Cathleen Cimino-Isaacs, "Labor Standards in the TPP", in Cathleen Cimino-Isaacs and Jeffrey J. Schott (eds.) Trans-Pacific partnership: An Assessment (Peterson Institute for International Economics, Washington D.C., 2016)264265.

${ }^{50}$ Supra footnote 48

51 The one exception to the rule is the EU-CARIFORUM Economic Partnership Agreement (EUCARIFORUM EPA). The EU-CARIFORUM EPA subjects disputes concerning sustainable development provisions to its dispute settlement mechanism, although even in that case, the ability to suspend market 
binding, the parties do not have the right to withdraw negotiated trade concessions in case of violations of labour rights by the other party. Instead, EU FTAs typically provide that where the parties are unable to resolve an issue regarding the sustainable development provisions, the parties may request that the matter be examined by a panel or group of experts, ${ }^{52}$ whose task it is to issue a report containing recommendations. Although these recommendations are not binding, the KOREU FTA,${ }^{53}$ the Colombia-Peru FTA,${ }^{54}$ the EU-CARIFORUM FTA,${ }^{55}$ the EU-Singapore FTA $^{56}$ and the CETA $^{57}$ all provide that the sustainable development committee must monitor the implementation of the recommendations by the parties.

The absence of 'hard enforcement' mechanisms in EU sustainable development chapters has been the focal point of an ongoing debate concerning the goal and effectiveness of these chapters. The European Parliament has consistently advocated the establishment of hard enforcement mechanisms in these agreements, in line with the existing US practice. In a 2010 resolution, it proposed the need to provide "recourse to a dispute settlement mechanism on an equal footing with the other parts of the agreement, with provision for fines to improve the situation in the sectors concerned, or at least a temporary suspension of certain trade benefits provided for under the agreement, in the event of an aggravated breach of these standards". ${ }^{58}$ These sentiments were recently repeated by the European Parliament when it stated that the provisions of the sustainable development chapters should be covered by a dispute settlement mechanism capable of issuing financial sanctions. However, the EU has rejected these proposals. Some have argued that the EU's stance is justified by the general reluctance of the EU's counterparts in trade negotiations to accept hard enforcement mechanisms in these fields. ${ }^{59}$ This would be consistent with the EU's oft-stated commitment that its FTAs should reflect the needs and demands of its trading partners, rather than simply imposing the EU's interest and values. As discussed, a number of countries do not look favourably upon trade-labour/environment linkages, and it has been reported these issues have proved controversial in the context of negotiations between the EU and developing economies. ${ }^{60}$ As previously mentioned, the EU has also suggested that imposing sanctions against developing countries for non-compliance with labour or environmental standards can be problematic in that they cause further economic harm to such countries. ${ }^{61}$ Viewed from this

access concessions as a result of the violation of any sustainable development objective is ruled out . Article 23(2) EC-EPA.

${ }^{52}$ Articles 189.6 \& 195.6 CEPA; Article 13.15 KOREU FTA; Article 284 Colombia-Peru FTA, Article 297-301 EU-CA FTA ; Article 13.16 EU-Singapore FTA.

${ }^{53}$ Article 13.15 (2) KOREU FTA.

${ }^{54}$ Article 185 (4) Colombia-Peru FTA.

55 Article 301 (3) EU-CA FTA.

${ }^{56}$ Article 13.17(9) EU-Singapore FTA.

57 . Article 23.11 CETA.

58 European Parliament resolution of 25 November 2010 on human rights and social and environmental standards in international trade agreements (2009/2219(INI)) P7_TA(2010)0434

${ }^{59}$ F. Hoffmeister, 'The deep and comprehensive free trade agreements of the European Union', in M. Cremona and T. Tamacs (eds.) Trade Liberalisation and standardisation - new directions in the low politics of the EU foreign policy CLEER Working Papers 2013/6. Available at: http://www.asser.nl.

${ }^{60}$ Bridges Weekly, "India-EU FTA Talks Hit Snags on IP, Environment, Labour" 5 May 2010 [available at: https://www.ictsd.org/bridges-news/bridges/news/india-eu-fta-talks-hit-snags-on-ipenvironment-labour]; Jan Wouters, Idesbald Goddeeris, Bregt Natens and Filip Ciortuz, "Some critical issues in EU-India Free Trade Agreement negotiations" Leuven Centre for Global Governance Studies Working Paper No. 102 February 2013, 12.

${ }^{61}$ Cecilia Malmstrom, European Parliament debate on sustainable development provisions of the EU-West Africa Economic Partnership Agreement 1 February 2016 O-000011/2016-B8-0108/2016. 
perspective, the EU's approach can be presented as evidence of its reluctance to engage in imperialistic practices by simply imposing its values on others through economic coercion. Such explanations, however, do not account for the omission of hard enforcement mechanisms in EU FTAs negotiated with trade partners that are not opposed to the enforcement of labour and environmental protection in trade agreements. A very recent example can be found in the EU's refusal to allow for the imposition of sanctions in case of violation of the CETA's sustainable development chapter despite the fact that Canada includes such provisions in its own FTAs. ${ }^{62}$ The CETA experience suggests that the EU is itself against the enforceability of the sustainable development chapters because of concerns that its own labour and environmental protection standards may be contested by its trade partners. ${ }^{63}$

\section{Impact of labour protection provisions in FTAs}

The question of whether the inclusion of labour provisions in FTAs actually leads to the adoption and enforcement of higher labour standards remains open. This is due in part to methodological challenges from the difficulty in establishing a causal relationship between the ratification of agreements and changes in labour conditions to the a lack of reliable data. ${ }^{64}$ There is also a clear discrepancy between the effects of the inclusion of labour protection standards in FTAs on developed county and developing county FTA signatories. It has been noted that in North-North agreements, labour provisions have barely impacted on the domestic regulatory systems of signatories. ${ }^{65}$ For example, whilst the EU-Korea FTA requires parties to respect and realise the fundamental rights and principles contained in the ILO Declaration, the reality is that South Korea has been severely criticised for violating core labour rights and is yet to sign four of the eight core ILO conventions. ${ }^{66}$

Assessing the impact of labour provisions in the context of FTAs between parties with power asymmetries is an altogether more complex task. With respect to the US, there is evidence that their FTAs have led to an improvement of labour rights protection in the territory of the signatories. For example, it has been shown that US trade partners tend to increase their labour standards significantly during the FTA negotiation process. ${ }^{67}$ This is generally attributed to the fact that the opposition of the U.S. Democratic Party to the signing of trade agreements with countries with low labour standards typically acts as an incentive for

Available at:

http://www.europarl.europa.eu/sides/getDoc.do?type=CRE\&reference=20160201\&secondRef=ITEM$014 \&$ language $=\mathrm{EN}$

${ }^{62}$ T. Fritz, "Analysis and Evaluation of the Comprehensive Economic and Trade Agreement (CETA) between the EU and Canada", January 2015 Hans-Böckler-Foundation Berlin, 29. Available at: http://thomas-fritz.org/english/analysis-and-evaluation-of-the-comprehensive-economic-and-tradeagreement-ceta-between-the-eu-and-canada.

${ }^{63}$ European Parliament, "Trade and sustainable development chapters in CETA", January 2017 Briefing 10

Available

at:

http://www.europarl.europa.eu/RegData/etudes/BRIE/2017/595894/EPRS_BRI(2017)595894_EN.pdf.

${ }^{64}$ For a review of the economic literature on the effect of labour standards commitments in trade agreements see: Samira Salem and Faina Rozental, "Labour Standards and Trade: A review of recent Empirical Evidence" Journal of International Commerce and Economics [2012] 4(2) 1-33.

${ }^{65}$ See Joo-Cheong Tham and Kenneth Ewing "Labour Clauses in the TPP and the TTIP: A Comparison Without a Difference?",(2006) Melbourne Journal of International Law 24

${ }^{66} \mathrm{Ibid}, 29$.

${ }^{67}$ Emilie M. Hafner-Burton, Forced to Be Good: Why Trade Agreements Boost Human Rights (Cornell University Press, 2009) 147-151; Kim Moonhawk, "Ex Ante Due Diligence: Formation of PTAs and Protection of Labor Rights” International Studies Quarterly [2012], 704-719/ 
the latter to undertake significant domestic reforms. ${ }^{68}$ Such "pre-ratification" ${ }^{69}$ or "preimplementation" conditionality ${ }^{70}$ has proved highly effective in that it enables the US to demand domestic reforms as a pre-condition for the entry into force of negotiated trade. ${ }^{71}$ However, whilst effective, this approach has also been the subject of some criticism, especially as the US has on a number of occasions demanded that its trading partners implement domestic reforms that were not initially provided for in trade agreements. ${ }^{72}$ Moreover, although there is evidence that developing countries that have signed a trade agreement with the US have tended to experience improvements in the enforcement of labour laws after the entry into force of such agreements, ${ }^{73}$ there are also multiple examples of US FTA partners failing to comply with their labour law commitments. ${ }^{74}$ Whilst a number of submissions have been filed in relation to violation of labour provisions in US FTAs, ${ }^{75}$ only the aforementioned CAFTA-DR dispute has led to actual arbitration procedure and ruling. And even if the existence of a dispute settlement mechanism has enabled the US to exert pressure on FTA parties to address deficiencies in the enforcement of labour rights, ${ }^{76}$ the effectiveness of dispute settlement as leverage has clear limits. A good example of this can be found in the context of the Bahrain-US FTA. ${ }^{77}$ In 2011, the US Trade Labour Office received a complaint from US trade unions alleging that Bahrain had targeted trade union leaders for dismissal as a result of their political activities and, in doing so, had violated the freedom of association and the right to organise and bargain collectively. ${ }^{78}$ The complaint paved the way for the opening of consultations, but whilst Bahrain did eventually reinstate a number of dismissed trade union leaders, ${ }^{79}$ violations of labour rights have persisted in the country. The lack of political will and resource limitations of the competent US bodies to systematically

\footnotetext{
${ }^{68}$ Holger Janusch, "Labor Standards in U.S. Trade Politics" Journal of World Trade [2015] 49(6) (2015), 1060-1065.

${ }^{69}$ Lorand Bartels, "The EU's approach to social standards and the TTIP" in S. Khorana (ed.) The Transatlantic Trade and Investment Partnership (TTIP) Negotiations between the EU and the USA: Caught between Myth and Reality? (CIDOB Ediciones, 2015) 95

70 John F. Hornbeck, "Free Trade Agreements: US Promotion and Oversight of Latin American Implementation”, December 2009, Inter-American Development Bank Policy Brief IDB-PB-I02.

${ }^{71}$ Jeffrey S. Vogt, "The Evolution of Labor Rights and Trade - A Transatlantic Comparison and Lessons for the" 18 (2015) Journal of International Economic Law 836-842.

Transatlantic Trade and Investment Partnership

${ }^{72}$ John F. Hornbeck, supra footnote 70, 21.

${ }^{73}$ Sabine Dewan and Lucas Roncomni, "US Free Trade Agreements and Enforcement of Labor Law in Latin America” IDB Working Paper Series No. IDB-WP-453, November 2015.

74 US Government Accountability Office (GAO), "U.S. Partners Are Addressing Labor Commitments, but More Monitoring and Enforcement Are Needed" November 2014 (available at: https://www.gao.gov/assets/670/666788.pdf); Brittany Cohan Baclawski, "Re-Thinking the WTO's Relationship to International Labor Standards: Is It Finally Time for a Global Approach" 48 (2016) Geo. J. Int'l L. 255.

75 Mary Jane Bolle, "Overview of Labor Enforcement Issues in Free Trade Agreements" Congressional Research Service, 22 February 2016

76 Axel Marx, Brecht Lein and Nicolás Brando, "The Protection of Labour Rights in Trade Agreements: The Case of the EU-Colombia Agreement”, 50(4) (2016) Journal of World Trade 603.

${ }_{77}$ Agreement between the Government of the United States and the Government of the Kingdom of Bahrain on the Establishment of a Free Trade Agreement, U.S.-Bahr., Sept. 14, 2004, 44 I.L.M. 544 [hereinafter US-Bahrain FTA].

${ }^{78}$ Yannick Radi, "Labor Provisions in Dispute Settlement in International Investment Agreements" in A. K. Bjorklund (ed.) Yearbook on International Investment Law and Policy 2014-2015 (Oxford University Press, 2015) 94-95.

${ }^{79} \mathrm{~J}$. Vogt, supra footnote $71,848-849$.
} 
carry out investigations are the main reasons given for the weak monitoring and enforcement of labour provisions in US FTAs. ${ }^{80}$

The picture is equally mixed with respect to EU FTA. Postnikov and Bastiaens have presented evidence that the cooperative frameworks established in EU FTAs and, in particular,that the increased involvement of civil society actors in these frameworks, has led to the improvement of labour rights in EU partner states. ${ }^{81}$ However, two more recent studies have shed light on the limitations of the EU's sustainable development chapters, both in terms of the implementation of minimum labour standards and the effectiveness of cooperation in stimulating compliance with such standards. Firstly, in a study focusing on the operation of the EU-Peru FTA, ${ }^{82}$ Orbie and Van de Putte have demonstrated that that not only has Peru failed to implement core ILO Core Conventions listed in the agreement, it has also lowered domestic labour protections and failed to establish domestic mechanisms for CSO consultation. ${ }^{83}$ Secondly, a study conducted by Marx, Lein and Brando drew similar conclusions with respect to the EU-Colombia FTA, with criticisms levelled at the EU's apparent soft-touch approach to monitoring compliance with labour commitments and questions being raised about the reduced incentive to comply with labour related provisions in this trade agreement in the absence of hard enforcement mechanisms. ${ }^{84}$ Both studies recommend the adoption of a more proactive approach to the monitoring of labour commitments, as well as the inclusion of hard enforcement mechanisms and trade sanctions as a "measure of last resort" ${ }^{\$ 5}$ to complement the EU's cooperative approach. ${ }^{86}$

In short, labour protection provisions included in EU and US FTAs have generally led to the adoption, and in some cases increased enforcement, of minimum labour standards. This has tended to be a one-way process, where large developed trade powers require smaller economies to implement higher standards of labour protection, whilst not subjecting themselves to similar disciplines. FTAs are therefore primarily being used to expand labour standards favoured by the EU and the US and, in doing so, to incrementally ratchet up standards. However, in both cases, the success of FTAs in improving labour conditions have been limited, in large part because the EU and the US have lacked either the political will or the resources to fully monitor, implement and/or enforce the labour components of these agreements.

\footnotetext{
${ }^{80}$ US GAO, supra footnote 74, 43-46; J. Vogt, supra footnote 71, 859.

${ }^{81}$ Evgeny Posnikov and Ida Bastiaens, "Does dialogue work? The effectiveness of labor standards in EU preferential trade agreements" Journal of European Public Policy [2014] 21(6), 923-940.

82 Jan Orbie and Lore Van de Putte, "Labour Rights in Peru and the EU trade Agreement: Compliance with commitments under the sustainable development chapter" OFSE Working Paper, August 2016. Available at: https://biblio.ugent.be/publication/8055501/file/8055504.pdf.

${ }^{83}$ Jan Orbie and Lorre Van den Putte, supra footnote 82, 31

${ }^{84}$ Axel Marx, Brecht Lein and Nicolás Brando, supra footnote 76, 599.

${ }^{85}$ Jan Orbie, and Lorre van den Putte supra footnote 82, 39

${ }^{86}$ Ibid; Axel Marx, Brecht Lein and Nicolás Brando, supra footnote 76, 603-604.
} 


\section{TTIP AND TPP - CONSOLIDATION OF EXISTING TEMPLATE}

\section{Mega-regionals - setting global rules and values?}

The near state of paralysis of the WTO since the collapse of the Doha Development round and the continued reluctance of the WTO membership to embrace the reform proposals put forward by larger industrialized nations has led the latter to shift their focus to other fora. In particular, free trade agreements have increasingly been used to promote the type of trade rules which have been continuously rejected by developing countries at the multilateral level since the 1990s. These "deep" FTAs regulate a host of issues, from technical norms, procurement, investment protection and intellectual property rights to social and environmental protection, which are largely untouched under WTO law. Initially these FTAs were mostly bilateral and concluded by and between developed and developing countries, where the former could use their superior bargaining power to push through their offensive economic interests and regulatory positions. ${ }^{87}$

More recently, however, there has been a trend towards the negotiation of so-called mega-regional agreements, such as the EU-US Transatlantic Trade and Investment Partnership (TTIP), Transpacific Partnership (TPP), and the China-backed Regional Comprehensive Economic Partnership (RCEP). These agreements are distinctive in terms of their geographical scale and the breadth and depth of topics addressed, and because of the goals that they pursue. The rationale for mega-regional FTAs goes beyond the circumvention of stunted multilateral negotiations or the pursual of economic interests - it is also fueled by geopolitical concerns. This is the case of the TPP, a trade agreement that includes countries such as Australia, Canada, Malaysia, Mexico, Singapore and Japan, and was borne out of the US Obama administration's choice to pivot its foreign policy towards the Asia-Pacific region to offset the mounting power of China. ${ }^{88}$ At the time, the TPP was seen not just as an opportunity to access the lucrative Asia-Pacific market, but also as a means to challenge China's attempts to become the central actor in economic governance in the region.

The negotiation of the TPP provided an incentive for the EU to also pursue its own mega-regional FTAs. This was in part due to the fact that the EU did not want to find itself in a position where its firms were being discriminated against in terms of accessing one of the biggest regional markets in the world, and on the outside of an agreement that would potentially set the benchmark for future trade rules. ${ }^{89}$ As a consequence, the EU decided to launch FTA negotiations with countries such as Japan, New Zealand and Austria and,

${ }^{87}$ Peter Drahos, "Weaving Webs of Influence: The United States, Free Trade Agreements and Dispute Resolution Journal of World Trade" [2007] 41(1), 200; L. Winters, "The WTO and Regional Trade Agreements: Is it all over for Multilateralism?”, EUI Working Papers, RSCAS 2015/94, 10.

${ }^{88}$ Gabriel Feylbermayr and Rahel Aichele, How to make TTIP inclusive for all? Potential economic impacts of the Transatlatic Trade and investment Partnership, Study for the IFO Institute, 30 August 2015, 25-27; L. Winters, supra footnote 87, 10.

${ }^{89}$ Daniel Hamilton and Steven Blockmans, "The Geostrategic Implications of TTIP” CEPS Special Report, No. 105 / April 2015, 9. Available at: https://www.ceps.eu/system/files/SR105\%20Geopolitics\%20of\%20TTIP\%20Hamilton\%20and\%20Blockma ns.pdf; Marek Wąsiński, "Europe Left Behind: Trans-Pacific Partnership and Its Impact on the EU" Polish Institute of International Affairs No. 92 (824), 19 October 2015 [available at: https://www.pism.pl/files/?id_plik=20683]; Krisztina Binder, "The Trans-Pacific Partnership (TPP) Potential regional and global impacts" European Parliamentary Research Service - briefing May 2016, 12 [available at: http://www.europarl.europa.eu/RegData/etudes/BRIE/2016/582028/EPRS_BRI(2016)582028_EN.pdf \} 
critically, to initiate talks with the US on the Transatlantic Trade and Investment Partnership (TTIP). Both the EU and the US framed the TPP and the TTIP as key instruments in the race with emerging economies, especially China, to define the future rules of international trade. In this light, the Obama administration stated that one of the main aims of the TPP was to set the "economic rules of the road before others will" America's values". ${ }^{91}$ This 'values driven trade agenda' placed a great deal emphasis on labour protection standards, with the TPP billed by its proponents as the "highest-standard trade agreement in history", arguing that "TPP sets a global precedent for doing trade right". 92 similar approach was followed on the other side of the Atlantic, where TTIP was described as being "about more than that economic boost, though. It is also about who will set global standards for the regulation of goods and services in the 21st century. TTIP would strengthen the hand of Europe and America in that process. And that means strengthening our shared Atlantic values, from the fundamentals of democracy and the rule of law, to key areas such as the environment and social standards". ${ }^{93}$ For the EU, the TTIP offered the opportunity not just to enshrine existing labour protection standards but also to "go further than ever before in a bilateral trade agreement to promote these standards at home and abroad". 94 The TPP and the TTIP were therefore both being packaged as trade agreements that would raise the bar in terms of ensuring high standards of labour protection and would set the template for future trade agreements.

\section{Labour protection standards and the TPP}

The TPP was described in some quarters as a potential game-changer for social rights in US FTAs ${ }^{95}$. Like other US FTAs, the TPP includes a comprehensive chapter on labour issues which requires parties to generally adopt laws and regulations on ILO core labour rights, namely the freedom of association and the effective recognition of the right to collective bargaining, the elimination of all forms of forced labour or compulsory labour, the effective abolition of child labour; and the elimination of discrimination in respect of employment and occupation. ${ }^{96}$ The agreement also includes broad obligations regarding domestic procedural guarantees, such as the requirement under Article 19(8) TPP to ensure that judicial proceedings for the enforcement of labour laws are fair, equitable and transparent, comply with due process of law and do not lead to unreasonable fees or time limits or

${ }^{90}$ Michael Froman, "If We Don't Write The Rules Of The Global Economy, Others Will”, GE Reports, 6 November 2015. Available at: http://www.gereports.com/amb-michael-froman-if-we-dont-writethe-rules-of-the-global-economy-others-will/.

${ }^{91}$ David Nakamura, "Deal reached on Pacific Rim trade pact in boost for Obama economic agenda", Washington $\quad$ Post, 5 October 2015. Available at: https://www.washingtonpost.com/business/economy/deal-reached-on-pacific-rim-tradepact/2015/10/05/7c567f00-6b56-11e5-b31c-d80d62b53e28 story.html?utm term=.90dacdc3f87e.

${ }^{92}$ Office of the United States Trade representative, "The President's Trade Agenda - 2016". Available at: https://ustr.gov/sites/default/files/2016-Trade-Policy-Agenda.

${ }_{93}$ Cecilia Malmstrom and J. Hill, "Don't believe the anti-TTIP hype - increasing trade is a nobrainer", The Guardian, $16 \quad$ February $2015 . \quad$ Available at: http://www.theguardian.com/commentisfree/2015/feb/16/ttip-transatlantic-trade-deal-businesses.

${ }^{94}$ Cecilia Malmstrom, “TTIP - what's in it for labour, environment and sustainable development?", 6 November 2015. Available at: https://ec.europa.eu/commission/2014-2019/malmstrom/blog/ttip-whats-itlabour-environment-and-sustainable-development_en.

${ }^{95}$ Ronald Brown, “Labor Implications of TPP”, Working Paper, East-West Center Workshop on Mega-regionalism - New Challenges for Trade and Innovation, 16. Available at: https://papers.ssrn.com/sol3/papers.cfm?abstract_id=2745524.

${ }^{96}$ Article 19(3) TPP. 
unwarranted delays. This obligation is then complemented by the standard non-derogation clause, which prohibits parties from weakening labour protections afforded in domestic legislation in order to encourage trade or investment, and an 'enforcement clause' requiring parties not to fail to enforce its laws through a sustained course of action or inaction. ${ }^{97}$

There is nothing particularly original or novel about the aforementioned provisions, which borrow extensively from the text of past US FTAs. However, one area where the TPP could be said to potentially depart from past practice is the negotiation of a number of bilateral side agreements negotiated between the US and Vietnam, Malaysia and Brunei - that is, those TPP parties which have been identified as maintaining relatively low labour standards and as having a poor record of ratifying ILO labour conventions. ${ }^{98}$ The side agreements provide that these countries must put into effect a number of reforms to their domestic regulatory systems in order to benefit from duty free access to the United States. ${ }^{99}$ Each of these side agreements contains detailed requirements for labour reforms that are specific to the concerned party. These include obligations to reform legislation on forced labour, child labour, protection of labour unions, union membership, collective bargaining, judicial proceedings and enforcement on labour matters. These side agreements are a de jure embodiment of the pre-ratification conditionality practice which, as discussed, has been employed to great effect by the US on several occasions in the past. It is a positive development from the perspective of the US's trading partners, in that they provide clarity and security in terms of the domestic reforms that must be implemented in order to benefit from concessions negotiated in the trade agreement, and avoids situations whereby additional reform requirements could be added after the signing of FTAs depending on the political whims of the US Congress.

From an institutional perspective, the TPP establishes a cooperative framework for the parties to discuss the implementation of the agreement as well as a variety of labour law issues both at a regional or multilateral level. The TPP establishes a Labour Council which would meet every two years unless decided otherwise by the parties, and counts among its functions the duty to agree on a general work programme concerning labour cooperation and capacity building activities, and to facilitate public participation and awareness of the implementation of the Labour Chapter. ${ }^{100}$ There is an obligation for each party to establish contact points to receive and consider written submissions from nationals of one the parties in relation to matters covered in the Labour Chapter which can then be reviewed by the TPP. The agreement follows past US FTA practice by a setting up a procedure allowing for bilateral cooperative dialogues between the parties ${ }^{101}$. Each party can make a written request to another party requesting a dialogue concerning a labour issue affecting trade or investment ${ }^{102}$. Through this dialogue, which must begin within 30 days from the submission of the written request, it is hoped that parties can collectively develop solutions to problems that arise from the lack of compliance and enforcement of labour laws, such as the development of action

${ }^{97}$ Article 19(5) TPP.

${ }^{98}$ Brunei Darussalam - United States Labour Consistency Plan, 4 February 2016; United States Malaysia Labor Consistency Plan, 4 February 2016, United States - Government of the Socialist Republic of Viet Nam Plan for the Enhancement of Trade and Labour Relations, 4 February 2016. Available at: https://ustr.gov/trade-agreements/free-trade-agreements/trans-pacific-partnership/tpp-full-text.

${ }^{99}$ Paragraph II Brunei Darussalam - United States Labour Consistency Plan; Paragraph II United States - Malaysia Labor Consistency Plan; Paragraph II United States - Government of the Socialist Republic of Viet Nam Plan for the Enhancement of Trade and Labour Relations.

${ }^{100}$ Article 19(12) TPP.

${ }^{101}$ Article 19(11) TPP.

${ }^{102}$ Article 19(11) (2) TPP. 
plans aiming at the promotion of labour inspections, independent verification of labour compliance and cooperative programmes and capacity building projects. ${ }^{103}$ Finally, all provisions of the Labour Chapter are subject to the TPP's dispute settlement procedure. Firstly, parties can request labour consultations with another party if they identify a matter that requires adjudication, and if no solution is found, the requesting party may request the establishment of a panel. ${ }^{104}$ Such panel will have the power to issue a report determining whether a violation of the agreement has occurred, and in the event where a responding party fails to rectify the violation, the complaining power has the rights to suspend benefits derived from the agreement. ${ }^{105}$ Here, again, it should be noted that the institutional provisions of the TPP are generally in line with past US FTAs.

\section{Labour protection standards and the TTIP}

In 2015, the EU issued a textual proposal dealing, inter alia, with the labour aspects of the TTIP (Textual Proposal). ${ }^{106}$ The proposal was limited in scope, in so far as it did not deal with institutional issues such as civil society participation and dispute settlement mechanisms. Instead, the proposal focuses exclusively on the promotion of substantive international labour norms, and in this respect at least, the EU has shown a willingness to build upon its existing template language. The proposal provides that each party must ensure that its laws and practices respect, promote and realise within an integrated strategy, in its whole territory and for all, the internationally recognised core labour standards which are the subject of ILO Conventions, namely: i) the freedom of association and the effective recognition of the right to collective bargaining; the elimination of all forms of forced labour or compulsory labour; the effective abolition of child labour; and the elimination of discrimination in respect of employment and occupation". ${ }^{107}$ This requirement to comply with core labour standards is in line with previous EU and US FTA practice. However, the textual Proposal departs from such practice by providing detailed descriptions of the various principles that are subsumed in these rights and must be upheld by the parties, as well as by listing measures that must be adopted in order to put these rights into practice. ${ }^{108}$ For example, with respect to the freedom of association and the right to collective bargaining, Article 5 of the Textual Proposal enjoins each party to uphold and implement in their laws and practices the right to form and join trade unions and the inherent corollary of the right to strike, the right to establish and join employers' organisations, the effective recognition of collective bargaining and effective social dialogue. In addition, the Textual Proposal also lists measures that must be put in place by the parties to ensure that these rights are realised in practice. Once more, in the area of the freedom of association, parties must implement effective policies and measures for social dialogue, for information and consultation of workers through dialogue, adequate protection against acts of anti-union discrimination, maintain the right to negotiate, conclude and enforce collective agreements, etc. ${ }^{109}$ This approach, which is replicated for all other core labour rights covered by the Textual Proposal, is designed not just to promote adoption and compliance with core labour rights, but also to set out in detail how such rights can be operationalised. In

${ }^{103}$ Article 19(11) (6) TPP.

${ }^{104}$ Article 19(15) TPP.

105 Article 18(20) TPP.

${ }^{106}$ EU Textual Proposal, 6 November 2015. Available at:

http://trade.ec.europa.eu/doclib/docs/2015/november/tradoc 153923.pdf.

${ }^{107}$ Article 4(2) Textual Proposal.

${ }^{108}$ Articles 5 to 9 Textual Proposal.

${ }^{109}$ Article 5(3) Textual Proposal. 
relation to 'working conditions', the Textual Proposal is far less ambitious in that it merely provides a broad obligation to ensure the protection of health and safety at work and decent working conditions for all. There is no detailed description of how such standards can be implemented in practice, and only a very brief and non-exhaustive list of areas and issues that must be covered by domestic legislation (e.g., decent working conditions must relate to wages and earnings, working hours and other conditions in order to ensure a minimum living wage). ${ }^{110}$

Beyond the dissemination of international norms, the Textual Proposal also follows current EU FTA practice by establishing by establishing a clear link between trade and labour standards. Article 7 of the Textual Proposal provides:

1. The Parties recognise that it is inappropriate to weaken or reduce the levels of protection afforded in domestic environmental or labour laws in order to encourage, or in a manner affecting, trade or investment.

2. A Party shall not waive or derogate from, or offer to waive or derogate from, its environmental or labour laws as an encouragement for, or in a manner affecting, trade or investment.

2. A Party shall not, through a sustained or recurring course of action or inaction, fail to effectively enforce its environmental or labour laws as an encouragement for, or in a manner affecting, trade or investment.

Paragraph 1 harks back to the EU-CARIFORUM EPA's non-lowering clause. However, unlike the EU-CARIFORUM EPA, this clause is phrased in non-binding terms, merely stating that parties must "recognise that it is inappropriate to weaken or reduce the levels of protection". ${ }^{111}$ With respect to paragraphs 2 and 3, this type of language, which is intended to prohibit parties from resorting to social dumping, can be found in other EU FTAs and is subject to a number of limitations, from the lack of clarity on the scope of labour provisions covered, to the difficulty in determining the causal link between derogation from standards and trade or investment and the absence of any enforcement mechanism. ${ }^{112}$ In short, barring a few additions, the Textual Proposal does not significantly deviate from standard EU FTA practice. The most notable change is that whilst not going as far as some EU FTAs which require the ratification and compliance with key ILO Conventions, the Textual Proposal would constitute an upgrade in terms of the minimum labour standards typically promoted in US FTAs.

\subsection{The collapse of TPP and TTIP and future of labour provisions in FTAs}

The analysis of both the text of the TPP Labour Chapter and the EU's textual proposal for the TTIP shows that the EU and the US have sought to use mega-regional agreements to consolidate and disseminate their existing template for labour provisions in trade agreements. Neither text shows a willingness on the part of their proponents to innovate or depart

${ }^{110}$ Article 4(3) Textual Proposal.

111 Article 17(1) Textual Proposal

112 Giovanni Gruni, "Law or Aspiration? The EU Proposal for a Labour Rights Clause in the Transatlantic Trade and Investment Partnership" Legal Issues of Economic Integration [2016] 43-44. 
significantly from the existing boilerplate language included in EU and US FTAs. In this sense, at least, the mega-regionals can be viewed as the latest instalment in the ongoing attempts of large industrialised powers to use their increased bargaining powers in the context of bilateral or regional trade agreements to impose regulatory positions that were rejected at the multilateral level, with the aim of incrementally raising labour standards whilst reducing the ability of countries to lower the application and enforcement of such standards to gain a competitive advantage in trade. This approach is not necessarily shared by others. Whilst the EU and the US pursued the TPP and the TTIP, emerging economies and smaller developing economies have also been occupied with the negotiation of their own mega-regionals. China, for example, does not include labour provisions in its FTAs. When signing FTAs with developed countries, it has exceptionally agreed to sign side agreements which do not create substantive obligations but rather best endeavour commitments to enforce existing international and domestic labour law obligations and to consider cooperation in certain fields. ${ }^{113}$ China has spearheaded the negotiation of the Regional Comprehensive Economic Partnership, an agreement that encompasses 16 Asian countries (including Australia, India and Japan) but largely eschews regulatory issues such as labour protection standards ${ }^{114}$. Similarly, the negotiation of a Continental Free Trade Area launched by the African Union largely focuses on trade liberalisation and investment protection whilst ignoring labour issues altogether. ${ }^{115}$ This, of course, should come as no surprise, to the extent that emerging and developing economies were the main opponents to the introduction of trade-labour linkages within the fabric of WTO law. In this sense, at least, the approach to trade-labour linkages adopted in mega-regionals largely mirrors the recent evolution of global trade governance and law. The venue for the negotiations of trade issues may have shifted from the multilateral to bilateral or regional settings, but the divisions and divergences which undermined reform at WTO level remain fundamentally the same.

However, the US's dalliance with mega-regional trade agreements seems to be at an end for the time being. On 23 January 2017, President Donald Trump signed an executive order formally ending the US' participation in the TPP. ${ }^{116}$ This followed a US presidential electoral campaign where President Trump routinely linked free trade and trade agreements with the loss of manufacturing jobs - a message that played very well with a significant portion of the US electorate - and vowed to radically change the US's approach to negotiating trade agreements. As for the EU, the prospect of concluding the TTIP was always a remote one. The TTIP negotiations have from the very start been beset by relentless criticism from the public, civil society, and politicians in Europe, because of its perceived threat to the regulatory autonomy of the EU and its Member States. There were concerns regarding the

${ }^{113}$ Henry S. Gao, "China New Zealand Free Trade Agreement", in Simon Lester and Bryan Mercurio (eds.), Bilateral and Regional Trade Agreements: Case Studies (Cambridge University Press, 2016) 93.

${ }^{114}$ David Gantz, "The TPP and RCEP: Mega-Trade Agreements for the Pacific Rim" Ariz. J. Int'l \& Comp. L. [2016] 33 57, 63; See also Mie Oba, "TPP, RCEP, and FTAAP: Mulitlayered Regional Economic Integration and International Relations", Asia-Pacific Review [2016] 23.1, 100-114; Meredith Kolsky Lewis, "The TPP and the RCEP (ASEAN6) as Potential Paths toward Deeper Asian Economic Integration", Asian J. WTO \& Int'l Health L \& Pol'y [2013] 8, 359.

${ }^{115}$ Laura Páez, "A Continental Free Trade Area: Imperatives for Realizing a Pan-African Market", Journal of World Trade 50.3 (2016), 533, 549. See also Vincent Angwenyi, "The Tripartite Free Trade Area: A Step Closer to the African Economic Community?" European Yearbook of International Economic Law (Springer, 2016) 589-613.

${ }^{116}$ Demetri Sevastopulo, Shawn Donnan and Courtney Weaver, "Trump pulls US out of Pacific trade pact" Financial Times, 23 January 2017. 
potential impact of the agreement on social and environmental standards, public services and, in particular, the potential of the investor-state dispute settlement (ISDS) mechanism to undermine the ability of EU Member States to legislate in pursuit of public interest objectives. The inauguration of Donald Trump - who has expressed a certain degree of antipathy towards the EU and a far more mercantilist approach to trade negotiations than his predecessors - has only served to further reinforce the suspicion that the chances of a successful conclusion to the TTIP negotiations remain extremely remote at this point in time.

What could be the impact of the demise of these mega-regional trade agreements on labour provision in EU and US trade agreements? At the time of writing, there is no indication that the US intends to substantively alter its approach with regard to the labour dimension of their FTAs. The current US administration has repeatedly signalled its intention to focus on the negotiation of bilateral trade agreements where it will be better placed to extract further concessions from its trade partners. Given the protectionist rhetoric adopted by this administration, it seems highly likely that the US will continue to require its trading partners to comply with minimum labour standards. Indeed, it may well wish to replicate the prescriptive approach to labour provisions developed in the TPP in future FTAs.

On the other side of the Atlantic, whilst recent FTAs concluded by the EU have stuck to the usual template ${ }^{117}$ there are also clear indications that the EU is willing to re-consider its approach to Trade and Sustainable Development chapters in EU FTAs. In a non-paper on 11 July $2017,{ }^{118}$ the European Commission signalled the intent to initiate a debate with the European Parliament and the Council of Ministers regarding the content of these chapters and, specifically, the question of their effective implementation and enforcement. The non-paper points to a series of concerns put forward by EU stakeholders on the functioning of the Trade and Sustainable Development chapters, from the lack of resources to implement the cooperative mechanisms to the non-usage of the dispute settlement mechanism foreseen in the chapters. In response to these criticisms, the EU puts forward two avenues for potential reform. The first option advocates continuity by proposing a "more assertive" stance to the current approach. For example, the non-paper suggests improving the complaints mechanisms by enhancing transparency of the process and clarifying steps to respond to inputs from stakeholders, improving the monitoring and follow up of sustainable development issues raised at governmental level, a more assertive use of the dispute settlement mechanism or improving the role of civil society organisations. This first option is not so much a reform proposal, as there are few suggestions that would lead to a substantive amendment of the existing EU FTA template. Rather it is an implicit recognition that the current trade and sustainable development chapters have not been effectively implemented. A rectification of this problem will in all likelihood necessitate an increase in the resources allocated to the European Commission and the EU's trading partners to monitor compliance and make use of the cooperative frameworks established by the FTAs.

Conversely, the second option would entail a considerable change from the current approach, as it opens the door for the use of trade sanctions in case of the violation of labour protection standards in a manner that affects trade. This is an approach that has been put

${ }^{117}$ See, for example, the proposed draft texts for the EU-Japan Economic Partnership Agreement. Available at: http://trade.ec.europa.eu/doclib/docs/2017/july/tradoc 155726.pdf.

118 European Commission, Non-Paper of the Commission services, "Trade and Sustainable Development (TSD) chapters in EU Free Trade Agreements FTAs)" 11 July 2017. Available at: http://trade.ec.europa.eu/doclib/press/index.cfm?id=1689. 
forward on different occasions by the European parliament and it is also one that would seek to provide an additional incentive for FTA parties to comply with the Trade and Sustainable Development chapters. It is not, however, an option favoured by the European Commission, with much of the non-paper dedicated to highlighting some of the limitations of hard enforcement mechanisms relating to labour/environment protection obligations in FTAs. For instance, the European Commission points to the fact that complaints can only be levelled in cases of non-compliance with labour standards that have a trade disrupting effect, and that providing evidence of economic injury resulting from non-compliance can be a challenging task. It also refers to ILO studies positing that hard enforcement mechanisms in FTAs are largely ineffective, and argues that a sanctions-based approach may be perceived as too confrontational a tool by the EU's trading partners, thus undermining the current emphasis placed by EU FTAs on the improvement of standards through long-term cooperation. The non-paper is thus subtly restating the European Commission's stance on the issue of Trade and Sustainable Development chapters - favouring cooperation and dialogue - which is in opposition that of the European Parliament, which argues for a more prescriptive approach. It is noteworthy in this regard that the non-paper does not put forward a third option - one where the current approach followed in EU FTAs would be complemented by hard enforcement mechanisms found in the US and Canada models. The European Commission's insistence on viewing conditional and promotional approaches as mutually exclusive, rather than potentially complementary, options seems odd in light of the concerns voiced regarding the lack of hard enforcement in agreements such as the EU-Colombia and EU-Peru FTAs ${ }^{119}$ and gives further credence to the suggestion that its aversion to hard enforcement mechanisms in this area is reflective of its concerns over the impact of sustainable development chapters on its own regulatory autonomy.

\section{CONCLUSION}

The TPP and the TTIP were both heralded by their proponents as an opportunity to set high standards and re-write the rules of the game in international trade. But when it comes to labour protection provisions, the reality is that the TPP and the textual proposals for the TTIP have not strayed far from the language typically found in recent EU and US FTAs. There is the odd innovation, such as the TPP side agreements, or the proposal for a non-binding nonlowering clause in the TTIP, but there is ultimately nothing that marks a significant departure with past FTA practice. In this sense, at least, these agreements could be seen as attempts to consolidate existing FTA templates whose aims are to incrementally raise labour standards whilst reducing the ability of countries to lower the application and enforcement of such standards to gain a competitive advantage in trade. At the time of writing, it would appear that these attempts have failed, as the chances of either agreement being concluded or/and ratified by the EU and the US are fairly remote. Nevertheless, the texts of these agreements provide a clear indication of the continued commitment by these two trade powers to use trade agreements as a tool to disseminate labour protection standards and remove the flexibility available to others to adjust domestic standards in order to promote trade or investment. On the one hand, this fits with Hafner-Burton's characterisation of the EU and the US as "liberal bullies, pushing for more economic liberalisation whilst at the same time forcing new

\footnotetext{
${ }^{119}$ See section III.2
} 
regulations that regulate human rights". ${ }^{120}$ On the other hand, there is also a growing body of evidence that the EU and the US have devoted relatively little attention to the actual implementation and continued enforcement of labour provisions included in their FTAs, indicating that once the agreements enter into force, their impact on domestic labour conditions of the parties tends to be limited. The argument against a more prescriptive approach based on the removal of concessions in the event of non-compliance is that such an approach can bear imperialistic undertones and, in any case, that sanctions can be counterproductive. But the fact that the disinclination of the EU and the US towards the use of hard enforcement mechanisms has also been accompanied by a lack of investment in resources to ensure the monitoring and implementation of the labour provisions in FTAs suggests that their commitment to use trade agreements to promote labour standards is, as things currently stand, half-hearted. For both then, and particularly the EU as it embarks on the review of its practice with respect to sustainable development chapters in FTAs, more consideration must be given to the development of mechanisms - from pre-ratification conditionality, hard enforcement mechanisms and increased investment on monitoring and capacity building - to improve the impact of these agreements on domestic labour conditions.

${ }^{120}$ Emilie M. Hafner-Burton, supra footnote 67, 141. 